\title{
SKILLS REQUIREMENTS IN SOUTH AFRICAN SUPPLY CHAINS: A HIGHER EDUCATION PERSPECTIVE
}

\author{
R. Luke* \\ e-mail: rluke@uj.ac.za

\section{G. J. Heyns*} \\ e-mail: gjheyns@uj.ac.za
}

*Department of Transport \& Supply Chain Management

Johannesburg Business School

University of Johannesburg, South Africa

\section{ABSTRACT}

In recent years, South African supply chains have struggled to move domestic and international freight efficiently and effectively. The purpose of this article is to determine the skills that students believe are required in the industry to determine whether there is a mismatch between the supply and the demand of supply chain management skills. The findings from this research suggest that, while industry has a need for technical (hard) skills, there is a stronger requirement for soft skills, which largely appear to be undervalued by students. This suggests that current curriculums focus on hard skills and do not meet the skill sets required by industry, which provides evidence of gaps within the current supply chain education programmes. This research provides an original contribution in that it is the only survey that gauges students' perspectives on logistics and supply chain requirements in South Africa and compares them to industry perspectives to provide a comprehensive overview of supply chain education in South Africa.

Keywords: supply chain skills, supply chain education, hard and soft skills, skills gap, skills shortage

\section{INTRODUCTION}

South Africa's economy is currently in a state of crisis. With GDP growth averaging 1.5 per cent per annum over the past five years and no real GDP per capita growth, the economy appears to be contracting. The outlook for the next few years shows no signs of improvement, with growth of approximately 0.8 per cent in 2017 and 1.6 per cent in 2018 . This contraction, while the rest of the world is in recovery, indicates clear structural issues within the economy (World Economic Forum 2017). This is reflected in the economic reports for the first quarter of 2017, where "both the secondary and tertiary sectors recorded negative growth rates. The trade and manufacturing industries were the major heavyweights that stifled production, with trade falling 
by $5.9 \%$ and manufacturing by $3.7 \%$ " (StatsSA 2017 ).

Although many reasons underlie the poor performance of the economy, one of the key issues lies within the labour force. Youth unemployment is over 55 per cent and general unemployment is approximately 25 per cent of the workforce. The unit cost of labour has increased at approximately 7.5 per cent per year on average. The implication is that, notwithstanding the depreciating Rand, South Africa's competitive position has deteriorated significantly. Despite high levels of unemployment, skills shortages remain acute, further impacting the country's competitive position. A key concern regarding skills is the quality of education, rated as $120^{\text {th }}$ of 140 countries in the World Economic Forum's Global Competitiveness Index, with higher secondary enrolment rates not being sufficient to produce the skills necessary for a competitive economy (World Economic Forum 2015).

Logistics and supply chain performance are critical to the effective functioning of the economy. In South Africa, logistics is estimated to comprise approximately 11.7 per cent of GDP and 53.6 per cent of transportable GDP (Havenga et al. 2016), which is considered high when compared to countries like the USA, estimated at 7.5 per cent (ATKearney 2017) or Germany, estimated at 8.6 per cent (Havenga et al. 2016). South Africa has considerable disadvantages from a supply chain perspective, such as its distances between ports and economic hubs as well as distances between economic hubs and major trading partners, making it a transport intensive economy (Havenga et al. 2016). This suggests that it is even more critical that supply chains function as effectively as possible.

When measuring logistics performance, available competencies are typically regarded as critical to the effective functioning of the supply chain (World Bank 2016). Although this index indicates marginal improvements in perceptions of logistics competence over the past ten years, both the Logistics Barometer (Havenga et al. 2016) and the Barloworld Supply Chain Foresight Report (2016) continue to identify the skills shortage as a critical constraint to South Africa's business environment in general and its supply chains in particular.

Although exacerbated by the education and labour market issues highlighted above, the skills shortage in the supply chain is not unique to South Africa, but rather appears to be a global concern. Mehta (2015) states that "rapidly expanding globalization and exponentially growing demand for supply chain professionals has created a vast gap between the demand and supply of skilled professionals for various supply chain areas". Clarke (2016) identifies that the causes for the skills shortage include: the industry is growing quicker than the workforce is becoming qualified; the qualifications necessary for supply chain careers are increasing; an education shortage exists; and companies have difficulties in judging a competent supply chain mind. The essence thus appears to be that the supply chain environment is evolving rapidly and, in 
doing so, requires a continuously evolving skill set, many of which cannot be gained by training alone, but rather through application and experience. According to Ferrari (2016),

"... the megatrends in business and technology are creating new and more demanding jobs with far more specialized, technology-grounded skill needs. Articulated essential skills now reflect on a broader combination of both hard and soft skills. There are needs for deeper crossfunctional business, supply chain and product management knowledge that span beyond a single function or a single international business culture. There are needs for cross-organizational team leadership, collaboration and change management skills, along with the ability to leverage appropriate technology tools for the challenge at hand."

In its analysis, a DHL Supply Chain report (2017) finds that "it is relatively easy to find people who are technically fit for jobs ... Finding talent with solid professional competencies is a bit tougher ... But the real challenge today comes when organizations try to find talent with both sets of attributes."

Based on the findings that both hard and soft skills are required to function effectively in a modern supply chain environment, a literature study was performed of recent supply chain research and opinion to ascertain the necessary skills for supply chain practitioners. For the purposes of this analysis, both academic articles and popular press articles and talent management perspectives were sought, in order to obtain a comprehensive range of perspectives on the skills needed by supply chain managers. While not considered to be exhaustive, repetition of key themes implied that a relative level of saturation had been achieved in the analysis. The results are shown in Table 1.

Table 1: Literature analysis on supply chain skills

\begin{tabular}{|c|c|c|}
\hline Hard skills & Soft skills & Source \\
\hline $\begin{array}{l}\text { Strategic supply chain management, } \\
\text { project management, technical knowledge }\end{array}$ & $\begin{array}{l}\text { Global business leadership, integrated business, } \\
\text { planning business communication }\end{array}$ & $\begin{array}{l}\text { All things supply } \\
\text { chain (2017) }\end{array}$ \\
\hline $\begin{array}{l}\text { Performance trade-offs, warehouse } \\
\text { management, transportation management, } \\
\text { supply chain synchronisation, risk } \\
\text { management, sustainability, location } \\
\text { facilities, distribution, warehousing, } \\
\text { logistics, international regulations, strategic } \\
\text { sourcing and supplier relationship, } \\
\text { customer relationship management, } \\
\text { applying lean and six sigma tools, enabling } \\
\text { technology, math, statistics and applied } \\
\text { science and technology, supply chain } \\
\text { fundamentals, foundations of business } \\
\text { management, operations and enterprise } \\
\text { economics }\end{array}$ & $\begin{array}{l}\text { Problem solving and decision making, teamwork and } \\
\text { collaboration, accountability and responsibility, } \\
\text { customer focus (internal and external), planning and } \\
\text { organising, conflict management, analytical thinking, } \\
\text { reading and writing for comprehension, personal } \\
\text { effectiveness competencies, awareness of the needs of } \\
\text { others, integrity, continuous learning, effective } \\
\text { communication, interpersonal skills, creativity }\end{array}$ & APICS (2014) \\
\hline $\begin{array}{l}\text { Process management, strategic, } \\
\text { quantitative }\end{array}$ & $\begin{array}{l}\text { People management, decision-making, behavioural, } \\
\text { negotiation }\end{array}$ & $\begin{array}{l}\text { Bak and Jordan } \\
(2017)\end{array}$ \\
\hline Technology & $\begin{array}{l}\text { Communication and analytical skills, interpersonal and } \\
\text { customer service skills }\end{array}$ & $\begin{array}{l}\text { Canadian } \\
\text { Logistics Skills } \\
\text { Committee } \\
(2005)\end{array}$ \\
\hline
\end{tabular}




\begin{tabular}{|c|c|c|}
\hline Hard skills & Soft skills & Source \\
\hline $\begin{array}{l}\text { Strategic orientation with a global } \\
\text { perspective, align strategic objectives of } \\
\text { SCM with the overall strategy of the } \\
\text { organisation, ability to manage change } \\
\text { processes and to balance the external } \\
\text { needs of the function with the internal } \\
\text { vision of efficiency, translate "client vision" } \\
\text { into strategic and operational practices }\end{array}$ & $\begin{array}{l}\text { Expertise to manage risk and uncertainty, motivate } \\
\text { people for mutualism and cooperation, obtain positive } \\
\text { operating performance of work teams, good } \\
\text { communication (written and oral) to influence their } \\
\text { subordinates and other parties related to the business } \\
\text { (including external partners), establish metrics and } \\
\text { reward systems aligned and coherent across functional } \\
\text { areas }\end{array}$ & $\begin{array}{l}\text { De Abreu and } \\
\text { Alcântara (2015) }\end{array}$ \\
\hline Technical, analytical skills & $\begin{array}{l}\text { Leadership, strategic and critical thinking, problem- } \\
\text { solving skills, creativity and imagination, people } \\
\text { development/mentoring/coaching skills }\end{array}$ & $\begin{array}{l}\text { DHL Supply } \\
\text { Chain (2017) }\end{array}$ \\
\hline \multirow[t]{2}{*}{$\begin{array}{l}\text { Inventory management and transport } \\
\text { management, supply chain awareness, } \\
\text { supply chain cost }\end{array}$} & $\begin{array}{l}\text { Cross-functional awareness, ability to see the big } \\
\text { picture, cross-functional coordination, teamwork, } \\
\text { customer service and information flow }\end{array}$ & $\begin{array}{l}\text { Rahman and } \\
\text { Yang (2009) }\end{array}$ \\
\hline & $\begin{array}{l}\text { Creating and communicating a vision, promoting and } \\
\text { bringing about change, building partnerships, capturing } \\
\text { and acting on insightful information, seizing and } \\
\text { creating opportunity at the right place and time, } \\
\text { consistently modelling honourable behaviour and best } \\
\text { practices, serving the best interests of the organisation } \\
\text { without being self-serving }\end{array}$ & Donati (2015) \\
\hline \multirow{2}{*}{$\begin{array}{l}\text { Analytical skills, strong category } \\
\text { knowledge, software knowledge, computer } \\
\text { skills, understanding of finance/ cost of } \\
\text { ownership, knowledge of global } \\
\text { geography/ economy }\end{array}$} & $\begin{array}{l}\text { Written and verbal communication skills, negotiation } \\
\text { skills, business acumen/ understanding of overall } \\
\text { business, presentation ability/ polish, ability to forge } \\
\text { strong relationships with stakeholders }\end{array}$ & Ferrari (2016) \\
\hline & $\begin{array}{l}\text { Problem solving, decision making, teamwork, ability to } \\
\text { see the big picture, prioritising, supply chain awareness, } \\
\text { cross-functional awareness and written and oral } \\
\text { communication }\end{array}$ & $\begin{array}{l}\text { Gammelgaard } \\
\text { and Larson } \\
(2001)\end{array}$ \\
\hline $\begin{array}{l}\text { Supplier development, information } \\
\text { systems, market understanding, supply } \\
\text { chain knowledge management, } \\
\text { performance measurement/prioritizing } \\
\text { supply chain improvements }\end{array}$ & $\begin{array}{l}\text { Complexity management, inter-firm relationship } \\
\text { skills/relationship management within process, } \\
\text { proactive management/risk management, skills/talent } \\
\text { management }\end{array}$ & $\begin{array}{l}\text { Gunasekaran, et } \\
\text { al. (2017) }\end{array}$ \\
\hline Information systems & $\begin{array}{l}\text { Customer service required, good communications skills } \\
\text { required for efficient coordination, critical analysis, } \\
\text { adaptability to changing requirements and an open } \\
\text { mind }\end{array}$ & $\begin{array}{l}\text { Kisperska- } \\
\text { Moron (2010) }\end{array}$ \\
\hline $\begin{array}{l}\text { Information technology and automation } \\
\text { knowledge, economics and market } \\
\text { dynamics, understanding cost-to-serve, } \\
\text { project management }\end{array}$ & Flexibility, ability to get the best from people & $\begin{array}{l}\text { Logistics Bureau } \\
\text { (2016) }\end{array}$ \\
\hline $\begin{array}{l}\text { Knowledge of logistics, supply chain } \\
\text { management and transportation, financial } \\
\text { planning, forecasting, workflow } \\
\text { optimization, general management and } \\
\text { business, international business practices, } \\
\text { knowledge of laws and regulations, } \\
\text { mechanical skills }\end{array}$ & Languages & $\begin{array}{l}\text { Logistics Bureau } \\
\text { (2017) }\end{array}$ \\
\hline $\begin{array}{l}\text { Finance, IT and management / strategy, } \\
\text { logistics / SCM }\end{array}$ & $\begin{array}{l}\text { Analytical, interpersonal, leadership, change } \\
\text { management and project management skills }\end{array}$ & $\begin{array}{l}\text { Mangan and } \\
\text { Christopher } \\
\text { (2005) }\end{array}$ \\
\hline IT, logistics / supply chain management & $\begin{array}{l}\text { Communications/negotiations, general experience and } \\
\text { people management }\end{array}$ & $\begin{array}{l}\text { Mangan, } \\
\text { Gregory and } \\
\text { Lalwani (2001) }\end{array}$ \\
\hline \multirow[t]{2}{*}{$\begin{array}{l}\text { Technical competencies (enabling them to } \\
\text { tackle, for example, complex aspects of } \\
\text { risk management, statistical modelling, and } \\
\text { multitier management) }\end{array}$} & $\begin{array}{l}\text { Strategic thinking and problem solving, leadership and } \\
\text { professional competencies (valuable in problem solving, } \\
\text { change management, and talent development) }\end{array}$ & $\begin{array}{l}\text { Material } \\
\text { handling and } \\
\text { logistics (n.d.) }\end{array}$ \\
\hline & $\begin{array}{l}\text { Be a decision maker, communication and networking } \\
\text { skills, understand how to use data and apply data } \\
\text { analytics }\end{array}$ & McAvoy (2016) \\
\hline $\begin{array}{l}\text { Knowledgeable in the latest technologies, } \\
\text { relevant technical training }\end{array}$ & Communication skills and knowledge on industry trends & McCrea (2012) \\
\hline
\end{tabular}




\begin{tabular}{|c|c|c|}
\hline Hard skills & Soft skills & Source \\
\hline Cross border supply chain regulation & $\begin{array}{l}\text { Communicating across borders, influencing senior } \\
\text { management and working collaboratively with suppliers, } \\
\text { communication, relationship management, negotiation } \\
\text { and influencing skills, moral integrity, insight to see past } \\
\text { cultural barriers when dealing with suppliers, the ability } \\
\text { to lead change in organisations or the power to } \\
\text { safeguard your business's reputation for a generation }\end{array}$ & Noble (2015) \\
\hline $\begin{array}{l}\text { Business skills - transportation and } \\
\text { logistics, human resource management, } \\
\text { general business administration and } \\
\text { information systems; Logistics skills - } \\
\text { transportation management; Management } \\
\text { skills - inventory control and demand } \\
\text { forecasting }\end{array}$ & $\begin{array}{l}\text { Business ethics, personal integrity, the ability to plan, } \\
\text { the ability to adapt to change, problem-solving abilities, } \\
\text { customer service }\end{array}$ & $\begin{array}{l}\text { Razzaque and } \\
\text { Bin Sirat (2001) }\end{array}$ \\
\hline $\begin{array}{l}\text { Analytical skills, e.g. data processing, } \\
\text { demand forecasting and performance } \\
\text { evaluation, project management, risk } \\
\text { management, stakeholder management } \\
\text { and decision-making, professional SCM } \\
\text { qualifications }\end{array}$ & $\begin{array}{l}\text { Communication, coordination and negotiation, } \\
\text { leadership }\end{array}$ & $\begin{array}{l}\text { Shou and Wang } \\
(2017)\end{array}$ \\
\hline Cost control & $\begin{array}{l}\text { Personal integrity, managing client relationships, } \\
\text { problem-solving ability and ability to plan }\end{array}$ & $\begin{array}{l}\text { Thai, Cahoon } \\
\text { and Tran (2011) }\end{array}$ \\
\hline
\end{tabular}

\section{RESEARCH METHODOLOGY}

The purpose of this research is to ascertain the critical logistics and supply chain management skill sets typically needed by organisations in Southern Africa at various levels and to compare these to students' perceptions of these requirements. The research aims to determine gaps to identify the educational interventions required at various points within the supply chain. Initially, a comprehensive list of skills considered as important by logistics and supply chain practitioners, as shown in Table 1, was identified from comparative studies. The initial skills list was reviewed and discussed by a panel of six academics and supply chain experts, selected for their teaching, research and industry experience. The skills list was further aligned with earlier skills identification processes (Heyns and Luke 2012). Based on this, a final list of 30 key hard and soft skills was selected and used for the purposes of survey and analysis.

To acquire an understanding of students' perception of the specific skill sets required by industry, a survey was conducted among tertiary students studying supply chain related courses at the University of Johannesburg (UJ). The student perception survey was distributed during April and May 2016 to approximately 4000 tertiary students, who were studying various subsidised (e.g. national diplomas and BCom degrees) and non-subsidised or industry programmes (e.g. certificates and diplomas). This research complies with the ethical requirements of $\mathrm{UJ}$, which ensure that the privacy and confidentiality of respondents were protected; that respondents provided consent and completed the survey voluntarily; and that respondents were informed that they could withdraw at any stage of the survey process.

The student responses were clustered into the three types of students, based on the types of courses they were studying, namely Industry Programmes (37\%) - part-time courses aimed 
at operational/tactical practitioners; Vocational Programmes $(32.6 \%)$ - practically orientated full-time courses; and Graduate Programmes (30.4\%) - traditional full-time academic programmes.

The research instrument, a self-administered questionnaire, containing six distinct segments, was used to collect the primary data. The first segment requested demographic information from the respondents; the second segment asked questions regarding the level of education and work experience students perceive to be required for the different management levels; section three and section four detailed six skills groups and 30 supply chain related skills items respectively; section 5 asked questions regarding students' perceptions of employability prospects; and finally, section 6 requested respondents to rate the service quality of the qualification they are currently studying.

In the student survey, respondents were requested to rate the perceived importance of the detailed skills groups and skills items typically required by logistics and supply chain organisations on a four-point Likert-type scale (anchored at $1=$ to no extent and $4=$ to large extent). The survey data was analysed using SPSS for Windows version 24.

\section{RESULTS}

The survey was completed by 1077 respondents, which represent a response rate of approximately 27 per cent of the 4000 curricular and non-curricular students studying supply chain related courses at UJ. The respondents' status indicates 50.8 per cent and 49.2 per cent enrolment for part-time and full-time studies, respectively. Table 2 provides a detailed breakdown of the respondents' profile across the type of qualification studied.

Table 2: Profile of respondents

\begin{tabular}{|l|c|c|c|r|}
\hline & Industry (\%) & Academic (\%) & Vocational (\%) & Total (\%) \\
\hline Respondents & 37 & 31 & 33 & 100 \\
\hline Male & 64 & 46 & 44 & 52 \\
\hline Female & 36 & 54 & 56 & 48 \\
\hline Full-time student & 3 & 92 & 68 & 51 \\
\hline Part-time student & 97 & 8 & 32 & 49 \\
\hline Employed & 59 & 25 & 37 & 42 \\
\hline Unemployed & 41 & 75 & 63 & 58 \\
\hline
\end{tabular}

$n=1077$

Respondents were asked to rate the importance of each of six skills groups on a 4-point Likerttype scale $(1=$ to no extent, $4=$ to a large extent $)$, as shown in Figure 2. General Management 
is considered to refer to aspects such as the ability to plan, organise, and control; Behavioural/Interpersonal skills are aspects such as time and diversity management, as well as people and social skills; Logistics Awareness focuses on issues such as seeing the "big picture" and the total cost concept; Logistics Analytical skills address key logistics elements, such as demand forecasting, transport and warehouse management, and quantitative analysis; Logistics IT considers software knowledge and computer skills; and Environmental Awareness describes activities such as reverse and green logistics (Heyns and Luke 2012).

Logistics Analytical skills were rated by the majority of the respondents (78\%) as very important. This was followed by General Management, with 74.3 per cent, and Logistics Awareness with 72.1 per cent. Table 3 depicts the mean ranking of the various skills groups for the different qualification levels. Although it may seem that the different qualification groups have similar attitudes regarding the skills groups, a statistical analysis indicated significant differences concerning the Behavioural/Interpersonal, General Management and Logistics Awareness skills groups.

Table 3: Importance of skills groups

\begin{tabular}{|l|c|c|c|c|c|c|}
\hline & \multicolumn{2}{|c|}{ Industry } & \multicolumn{2}{c|}{ Academic } & \multicolumn{2}{c|}{ Vocational } \\
\hline Skills Group & Mean & Std. Dev & Mean & Std. Dev & Mean & Std. Dev \\
\hline Logistics IT (LIT) & 3.48 & 0.71 & 3.52 & 0.64 & 3.46 & 0.64 \\
\hline Environmental Awareness (EA) & 3.48 & 0.66 & 3.42 & 0.67 & 3.44 & 0.64 \\
\hline Behavioural/Interpersonal skills (B/I) & 3.57 & 0.58 & 3.35 & 0.71 & 3.50 & 0.59 \\
\hline Logistics Awareness (LA) & 3.67 & 0.57 & 3.74 & 0.50 & 3.72 & 1.65 \\
\hline General Management (GM) & 3.71 & 0.57 & 3.63 & 0.58 & 3.77 & 0.49 \\
\hline Logistics Analytical (LAN) & 3.73 & 0.53 & 3.80 & 0.48 & 3.77 & 0.49 \\
\hline & \multicolumn{2}{|c|}{$n=363$} & \multicolumn{2}{|c|}{$n=323$} & & $n=331$ \\
\hline
\end{tabular}

The student perception survey required respondents to indicate, on a 4-point Likert-type scale, their agreement with a list of 30 skills (Heyns and Luke 2012) they perceive as important for logistics and supply chain employees. Table 4 shows the descriptive statistical results of these skills items and presents the mean ranking of the skills in terms of their perceived importance. The reliability of the measurement scale was evaluated to determine the internal consistency, indicating a Cronbach's $\alpha$ value of 0.887 , which suggests good reliability (Field 2013).

Table 4: Mean rating of skills items

\begin{tabular}{|l|c|c|}
\hline \multicolumn{1}{|c|}{ Skill } & Mean & Std. Dev \\
\hline Transport management & 3.78 & 0.46 \\
\hline Knowledge of the industry & 3.74 & 1.71 \\
\hline
\end{tabular}

\begin{tabular}{|l|c|c|}
\hline \multicolumn{1}{|c|}{ Skill } & Mean & Std. Dev \\
\hline Inventory management & 3.63 & 0.59 \\
\hline Laws and regulations & 3.62 & 1.41 \\
\hline
\end{tabular}




\begin{tabular}{|l|c|c|}
\hline \multicolumn{1}{|c|}{ Skill } & Mean & Std. Dev \\
\hline Decision making & 3.73 & 0.51 \\
\hline Problem solving & 3.72 & 0.53 \\
\hline Warehousing/MH management & 3.72 & 0.51 \\
\hline Ability to plan and prioritise & 3.69 & 0.54 \\
\hline Customer focus & 3.69 & 0.57 \\
\hline Communication skills & 3.68 & 0.55 \\
\hline Procurement/Purchasing & 3.68 & 0.56 \\
\hline Team work & 3.68 & 0.53 \\
\hline Quality management & 3.67 & 0.56 \\
\hline Supply chain cost knowledge & 3.67 & 0.54 \\
\hline Business ethics & 3.65 & 0.53 \\
\hline Demand forecasting & 3.64 & 0.58 \\
\hline Ability to think outside the box & 3.63 & 0.56 \\
\hline
\end{tabular}

\begin{tabular}{|l|c|c|}
\hline \multicolumn{1}{|c|}{ Skill } & Mean & Std. Dev \\
\hline Leadership & 3.62 & 0.59 \\
\hline Negotiating skill & 3.62 & 0.61 \\
\hline Supply chain design & 3.62 & 0.59 \\
\hline Ability to see big picture & 3.58 & 0.59 \\
\hline Business process improvement & 3.55 & 0.58 \\
\hline Quantitative/statistical skills & 3.53 & 0.62 \\
\hline Reverse logistics & 3.51 & 0.65 \\
\hline Cross-functional coordination & 3.47 & 0.65 \\
\hline Motivation skills & 3.44 & 0.67 \\
\hline Green logistics & 3.41 & 0.69 \\
\hline Change management & 3.35 & 0.70 \\
\hline IT skills/software knowledge & 3.34 & 0.70 \\
\hline Spreadsheet abilities & 3.34 & 0.71 \\
\hline
\end{tabular}

The most important logistics and supply chain related skills, as perceived by all the student respondents, are "Transport management" followed closely by "Knowledge of the industry", "Decision making", "Problem solving" and "Warehouse management". The rankings differ considerably between the various qualification groups. It appears that for the academic grouping, the students' highest ranking skills comprise more so-called hard skills (e.g. transport and warehouse management). This result is further illustrated by the results from the students' top skills group rankings (depicted in Table 4), which indicate that they view hard skills (e.g. Logistics Analytical skills) as more important than softer skills (e.g. Behavioural/ Interpersonal). In contrast, the industry student grouping placed less importance on hard skills with only one Logistics Awareness skill and four Behavioural/Interpersonal skills in their top 10 ranking. The vocational students' ranking indicates a more balanced split between hard and soft skills. The composition of the top 10 skills ranking for the different qualification groupings is depicted in Table 5.

Table 5: Top skills groups

\begin{tabular}{|l|c|c|c|}
\hline \multicolumn{1}{|c|}{ Skills Group } & Academic & Industry & Vocational \\
\hline Logistics Analytical (LAN) & 5 & 1 & 3 \\
\hline Logistics Awareness (LA) & 1 & 2 & 2 \\
\hline Behavioural/Interpersonal Skills (B/I) & 2 & 4 & 3 \\
\hline General Management (GM) & 2 & 3 & 2 \\
\hline
\end{tabular}

To evaluate if there are any significant statistical differences between different student groups, the response data were categorised into three main groupings and then analysed, viz. Qualification grouping (i.e. Academic, Industry, and Vocational programmes); Employment grouping (i.e. employed and unemployed); and Work experience grouping (e.g. 0 years, 1-3 
years, 4-10 years, $11-15$ years, and $>15$ years).

The Mann-Whitney U test was used to test for differences between the two independent groups (i.e. employed and unemployed students). The Kruskall-Wallis $\mathrm{H}$ test was used to compare the scores of three or more groups (e.g. qualification levels) (Pallant 2016). The MannWhitney $U$ test was then used to identify the specific sample pairs for significant differences. The statistical results for comparing the various respondent groups are depicted in Table 6 .

As indicated previously, most of the respondents are unemployed (58\%). When comparing the importance ranking of the skills items of employed and unemployed students, the results indicate that there are significant differences in 16 (out of 30) of the skills items. This is illustrated in Table 6. Of the 16 skills where significant differences were observed, 11 were considered to be soft skills. Employed people tended to provide a higher rating to all these skills items, thereby reinforcing the perspective that experience within the work environment provides a more realistic picture of industry requirements and that more emphasis is then placed on the softer skills. When considering the five remaining hard skills in which differences were observed, these are broader hard skills, such as business process improvement, and change management. This also clearly recognises the importance of "big picture" hard skills within the supply chain environment.

To test if there are any significant differences between the qualification groupings, the Kruskall-Wallis test was used to compare the responses of the academic, industry and vocational programme respondents (see Table 6). Significant differences were identified in 10 (out of 30) of the skills items. In nearly all the cases, significant differences occur between the academic and other groups. The skills items in which differences were observed were similar to those observed in the unemployed/employed differences, described above. It would appear that academic programme respondents rate these skills items as being of lower value than do their industry and vocational programme counterparts and therefore appear less realistic about industry requirements. This can primarily be ascribed to the profile of these students, who are mostly young, full-time students, with little to no work experience and therefore little exposure to the way in which industry functions and to real world requirements. This clearly indicates a requirement to focus educational efforts on filling these gaps.

When comparing the importance ranking of the respondents with different working experiences, the Kruskall-Wallis test identified eight skills items where significant differences occur. The post-hoc Mann-Whitney test identified that the majority ( 6 of the 8 incidences) of the differences occur between the 1-3 years' and 11-15 years' experience groups. As would be expected from the above results, respondents with more working experience valued the softer skills and bigger picture hard skills more highly than did respondents with low levels of work 
Table 6: Statistical results for different respondent groupings

\begin{tabular}{|c|c|c|c|c|c|c|c|c|c|c|c|c|c|c|c|c|}
\hline \multirow{3}{*}{ Skills Item } & \multirow{2}{*}{\multicolumn{4}{|c|}{$\begin{array}{c}\text { Employment grouping } \\
\text { Mann-Whitney U Test }\end{array}$}} & \multicolumn{6}{|c|}{ Qualification grouping } & \multicolumn{6}{|c|}{ Work experience grouping } \\
\hline & & & & & \multicolumn{4}{|c|}{ Kruskal-Wallis H Test } & \multicolumn{2}{|c|}{ Mann-Whitney U Test } & \multicolumn{4}{|c|}{ Kruskal-Wallis HTest } & \multicolumn{2}{|r|}{ Mann-Whitney U Test } \\
\hline & Mann-Whitney & $p$ value & $\mathrm{H}$ & Effect size $^{1}$ & Chi-Square & df & $p$ value & $\mathrm{H}$ & adj p value ${ }^{2}$ & Post-hoc test & Chi-Square & df & $p$ value & $\mathbf{H}$ & adj $p$ value ${ }^{2}$ & Post-hoc test \\
\hline Ability to plan and prioritise & 101067.5 & 0.001 & reject & 0.106 & 1.698 & 2 & 0.428 & retain & & & 12.726 & 4 & 0.013 & reject & 0.016 & Diff: $0->15 y$ \\
\hline Ability to see big picture & 98368.0 & 0.000 & reject & 0.119 & 4.006 & 2 & 0.135 & retain & & & 13.862 & 4 & 0.008 & reject & $0.05 \& 1.016$ & Diff: $1-3 y:>15 y, 1-3 y \& 11-15 y$ \\
\hline Ability to think outside the box & 103154.5 & 0.014 & reject & 0.079 & 9.007 & 2 & 0.011 & reject & 0.011 & Diff: Aca - Ind & 13.717 & 4 & 0.008 & reject & 0.014 & Diff: $1-3 y \& 11-15 y$ \\
\hline Business ethics & 106936.0 & 0.284 & retain & 0.035 & 7.942 & 2 & 0.019 & reject & 0.019 & Diff: Aca - Voc & 2.993 & 4 & 0.559 & retain & & \\
\hline Business process improvement & 99945.5 & 0.002 & reject & 0.102 & 5.364 & 2 & 0.068 & retain & & & 8.577 & 4 & 0.073 & retain & & \\
\hline Change management & 95560.5 & 0.000 & reject & 0.130 & 3.484 & 2 & 0.175 & retain & & & 14.28 & 4 & 0.006 & reject & $0.041 \& 0.05$ & Diff: $1-3 y \& 4-10 y ; 1-3 y \&>15 y$ \\
\hline Communication skills & 101932.5 & 0.003 & reject & 0.096 & 2.703 & 2 & 0.259 & retain & & & 3.157 & 4 & 0.532 & retain & & \\
\hline Cross-functional coordination skills & 98700.5 & 0.001 & reject & 0.105 & 3.692 & 2 & 0.158 & retain & & & 12.971 & 4 & 0.011 & reject & 0.012 & Diff: $1-3 y \& 11-15 y$ \\
\hline Customer focus & 102390.0 & 0.003 & reject & 0.097 & 10.846 & 2 & 0.004 & reject & $0.006 \& 0.034$ & Diff: Aca - Ind \& Voc - Ind & 9.845 & 4 & 0.043 & reject & & \\
\hline Decision making & 104631.0 & 0.038 & reject & 0.067 & 1.849 & 2 & 0.397 & retain & & & 13.188 & 4 & 0.01 & reject & 0.006 & Diff: $1-3 y \& 11-15 y$ \\
\hline Demand forecasting & 107325.0 & 0.316 & retain & 0.032 & 0.807 & 2 & 0.668 & retain & & & 3.47 & 4 & 0.482 & retain & & \\
\hline Green logistics / environmental issues & 108240.0 & 0.427 & retain & 0.026 & 0.166 & 2 & 0.920 & retain & & & 7.535 & 4 & 0.11 & retain & & \\
\hline Inventory management & 109422.5 & 0.909 & retain & 0.004 & 2.29 & 2 & 0.318 & retain & & & 3.642 & 4 & 0.457 & retain & & \\
\hline IT skills / software knowledge & 107639.0 & 0.336 & retain & 0.031 & 3.974 & 2 & 0.137 & retain & & & 5.268 & 4 & 0.261 & retain & & \\
\hline Knowledge of the industry & 102825.5 & 0.035 & reject & 0.068 & 0.108 & 2 & 0.947 & retain & & & 0.662 & 4 & 0.956 & retain & & \\
\hline Laws \& regulations & 98763.5 & 0.001 & reject & 0.109 & 16.38 & 2 & 0.000 & reject & $0.001 \& 0.003$ & Diff: Aca - Ind \& Voc - Ind & 2.21 & 4 & 0.697 & retain & & \\
\hline Leadership & 100834.0 & 0.007 & reject & 0.088 & 14.592 & 2 & 0.001 & reject & $0.001 \& 0.027$ & Diff: Aca - Ind \& Voc - Ind & 10.46 & 4 & 0.033 & reject & 0.018 & Diff: $1-3 y \& 11-15 y$ \\
\hline Motivation skills & 95105.5 & 0.000 & reject & 0.141 & 17.65 & 2 & 0.000 & reject & 0.000 & Diff: Aca - Ind & 8.806 & 4 & 0.066 & retain & & \\
\hline Negotiating skill & 102255.0 & 0.020 & reject & 0.075 & 9.899 & 2 & 0.007 & reject & $0.047 \& 0.009$ & Diff: Aca - Ind \& Aca - Voc & 14.463 & 4 & 0.006 & reject & 0.01 & Diff: $1-3 y \&$ 11-15y \\
\hline Problem solving & 106238.5 & 0.116 & retain & 0.051 & 0.247 & 2 & 0.884 & retain & & & 4.735 & 4 & 0.316 & retain & & \\
\hline Procurement / Purchasing & 107693.0 & 0.390 & retain & 0.028 & 12.04 & 2 & 0.002 & reject & 0.002 & Diff: Ind - Voc & 8.193 & 4 & 0.085 & retain & & \\
\hline Quality management & 104940.0 & 0.079 & retain & 0.057 & 0.655 & 2 & 0.721 & retain & & & 1.239 & 4 & 0.872 & retain & & \\
\hline Quantitative and/or statistical skills & 105501.0 & 0.196 & retain & 0.042 & 0.738 & 2 & 0.692 & retain & & & 4.71 & 4 & 0.318 & retain & & \\
\hline Reverse logistics & 108517.5 & 0.627 & retain & 0.016 & 0.936 & 2 & 0.626 & retain & & & 2.985 & 4 & 0.56 & retain & & \\
\hline Spreadsheet abilities & 92062.0 & 0.000 & reject & 0.158 & 10.629 & 2 & 0.005 & reject & 0.003 & Diff: Aca - Ind & 10.047 & 4 & 0.04 & reject & & \\
\hline Supply chain cost knowledge & 106583.5 & 0.162 & retain & 0.045 & 0.071 & 2 & 0.965 & retain & & & 2.271 & 4 & 0.686 & retain & & \\
\hline Supply chain design & 105856.0 & 0.161 & retain & 0.045 & 4.355 & 2 & 0.113 & retain & & & 3.685 & 4 & 0.45 & retain & & \\
\hline Team work & 97626.0 & 0.000 & reject & 0.130 & 7.487 & 2 & 0.024 & reject & 0.021 & Diff: Aca - Ind & 8.289 & 4 & 0.082 & retain & & \\
\hline Transport management & 105201.0 & 0.062 & retain & 0.060 & 5.326 & 2 & 0.070 & retain & & & 4.174 & 4 & 0.383 & retain & & \\
\hline Warehousing / MHE & 110169.5 & 0.763 & retain & 0.010 & 2.382 & 2 & 0.304 & retain & & & 5.829 & 4 & 0.212 & retain & & \\
\hline
\end{tabular}


experience. This again indicates the need to enhance these skills at early levels within the curriculums.

The respondents were also asked to indicate the level of education they believe to be required at various employment levels (i.e. operational, tactical and strategic). The results, shown in Table 7, indicate that the majority of students, across all the qualification groupings, think a certificate or diploma is the required tertiary qualification to obtain an entry level or operational level position. For tactical level positions, as could possibly be expected, academic programme students place a higher premium on bachelor's and honours degrees, as opposed to certificate or diploma qualifications as indicated by the industry and vocational students.

For strategic level positions, the majority of the respondents from all qualification groupings indicated that at least a bachelor's degree was required; however, the academic students placed a slightly higher importance on postgraduate degrees.

Table 7: Student perceptions of educational requirements

\begin{tabular}{|c|c|c|c|c|c|c|c|c|c|c|c|c|}
\hline \multirow[b]{2}{*}{ Qualification level } & \multicolumn{4}{|c|}{ Operational level } & \multicolumn{4}{|c|}{ Tactical level } & \multicolumn{4}{|c|}{ Strategic level } \\
\hline & 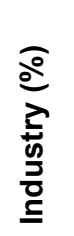 & 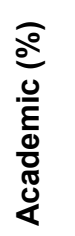 & 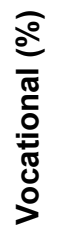 & $\frac{\grave{\S}}{\bar{\alpha}}$ & 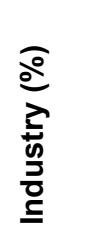 & 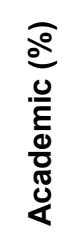 & 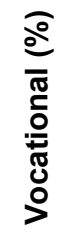 & $\frac{\widehat{Ð}}{\bar{\varepsilon}}$ & 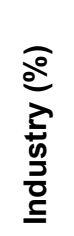 & 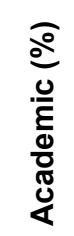 & 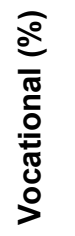 & $\frac{\grave{\varrho}}{\bar{\alpha}}$ \\
\hline PhD & 0.5 & 0.0 & 0.0 & 0.2 & 0.5 & 0.7 & 1.2 & 0.8 & 7.4 & 8.3 & 8.7 & 8.1 \\
\hline Master's Degree & 1.8 & 1.0 & 1.2 & 1.4 & 4.5 & 6.3 & 4.2 & 4.9 & 24.2 & 35.0 & 25.0 & 27.7 \\
\hline Honours Degree & 3.7 & 8.0 & 3.3 & 4.9 & 8.5 & 26.3 & 12.3 & 15.0 & 25.3 & 43.0 & 35.8 & 34.0 \\
\hline Bachelor Degree & 8.9 & 16.0 & 9.7 & 11.3 & 37.3 & 57.3 & 47.9 & 46.7 & 34.5 & 12.7 & 26.2 & 25.3 \\
\hline Certificate or Diploma & 46.1 & 39.0 & 51.8 & 45.8 & 47.6 & 9.0 & 34.1 & 31.7 & 8.2 & 0.7 & 4.2 & 4.6 \\
\hline High School & 38.4 & 34.0 & 30.6 & 34.6 & 1.6 & 0.3 & 0.3 & 0.8 & 0.5 & 0.0 & 0.0 & 0.2 \\
\hline Education not important & 0.5 & 2.0 & 3.3 & 1.9 & 0.0 & 0.0 & 0.0 & 0.0 & 0.0 & 0.3 & 0.0 & 0.1 \\
\hline
\end{tabular}

The respondents were furthermore requested to indicate the work experience they believed was required at the various employment levels. The results, as shown in Table 8, reveal that work experience, at all managerial levels, is important but explicitly so at strategic level. The industry students, however, placed somewhat more importance on work experience than did the academic and vocational programme students.

To assess the student respondents' employment expectations for the year following the attainment of their qualification, the data from the survey were grouped into programme clusters. The majority of the respondents from the industry programmes $(68.5 \%)$ are currently employed at an operational level, with an average of more than 10 years' work experience and 7 years' specific supply chain management experience. 
Table 8: Student perceptions of work experience requirements

\begin{tabular}{|c|c|c|c|c|c|c|c|c|c|c|c|c|}
\hline \multirow[b]{2}{*}{ Work experience } & \multicolumn{4}{|c|}{ Operational level } & \multicolumn{4}{|c|}{ Tactical level } & \multicolumn{4}{|c|}{ Strategic level } \\
\hline & 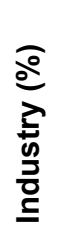 & 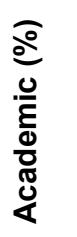 & 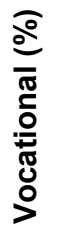 & $\frac{\overparen{\varrho}}{\grave{\&}}$ & 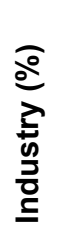 & $\begin{array}{l}\widehat{o} \\
\frac{0}{0} \\
\frac{0}{\varepsilon} \\
0 \\
\frac{0}{0} \\
\frac{0}{4}\end{array}$ & $\begin{array}{l}\widehat{0} \\
\frac{0}{\pi} \\
\frac{0}{c} \\
\frac{0}{7} \\
\frac{\pi}{0} \\
0 \\
0\end{array}$ & $\frac{\widehat{\varrho}}{\bar{\alpha}}$ & 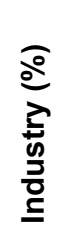 & 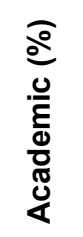 & $\begin{array}{l}\widehat{0} \\
\overline{0} \\
\frac{0}{0} \\
\frac{0}{0} \\
\frac{7}{0} \\
0 \\
0\end{array}$ & $\frac{\mathfrak{o}}{\bar{c}}$ \\
\hline$>5$ years & 4.1 & 2.2 & 2.0 & 2.8 & 12.6 & 3.6 & 6.1 & 7.8 & 58.2 & 50.0 & 50.8 & 53.3 \\
\hline $3-5$ years & 12.1 & 5.0 & 9.0 & 8.9 & 36.0 & 33.2 & 36.9 & 35.4 & 24.0 & 31.1 & 31.9 & 28.7 \\
\hline $1-3$ years & 34.1 & 32.7 & 29.3 & 32.1 & 36.8 & 47.3 & 40.3 & 41.1 & 12.0 & 12.1 & 9.5 & 11.2 \\
\hline$<1$ year & 12.6 & 18.0 & 16.7 & 15.6 & 6.4 & 7.9 & 6.8 & 7.0 & 1.8 & 0.7 & 1.7 & 1.4 \\
\hline Depends & 31.2 & 34.2 & 36.7 & 33.9 & 7.9 & 7.2 & 9.5 & 8.2 & 3.5 & 5.7 & 5.8 & 4.9 \\
\hline Not required & 5.9 & 7.9 & 6.3 & 6.6 & 0.3 & 0.7 & 0.3 & 0.4 & 0.6 & 0.4 & 0.3 & 0.4 \\
\hline
\end{tabular}

The results indicate that the industry students have relatively realistic employment expectations of advancing to the tactical management level (51\%), although a somewhat large number (39\%) envisage strategic level employment in the following year after concluding their qualification. The employment expectations of traditional academic programme students seem to be slightly less realistic, with more than 46 per cent believing they would be employed at a strategic management level within the next year, especially considering that only 24.6 per cent have parttime or full-time employment, mostly at operational level (49\%). These results are shown in Table 9.

Table 9: Employment expectations

\begin{tabular}{|l|c|c|c|}
\hline \multicolumn{1}{|c|}{ Programme } & Operational level & Tactical level & Strategic level \\
\hline Industry Programme & $9.4 \%$ & $51.4 \%$ & $39.1 \%$ \\
\hline Academic Programme & $6.3 \%$ & $47.5 \%$ & $46.2 \%$ \\
\hline Vocational Programme & $10.8 \%$ & $50.0 \%$ & $39.2 \%$ \\
\hline
\end{tabular}

\section{CONCLUSION}

The purpose of this article was to assess the skill sets that supply chain students typically believe logistics and supply chain organisations in South Africa require and to compare these skills with industry requirements.

The initial analysis of the six skills groups indicated that the different qualification groupings place significant importance on the hard skills groups with crucial areas being indicated as Logistics Analytical Skills, General Management, and Logistics Awareness. Significant differences occur, in all cases, in the Behavioural/Interpersonal, General Management, and Logistics Awareness skills groups between the academic and vocational students.

When asked to rate the specific skills required in the industry, the most important logistics 
and supply chain related skills, as perceived by all the student respondents, are "Transport management" followed closely by "Knowledge of the industry", "Decision making", "Problem solving" and then "Warehouse management". It is noticeable that the ranking differs between the various qualification groups, with the academic students identifying hard skills as more important than did the industry and vocational students. A study by Rahman and Qing (2014) also found that students tended to over-emphasise the importance of hard skills over soft skills.

The research also indicates that, although there are some differences between the perceptions of the three qualification levels regarding the education and work experience required for the three managerial levels, in general, it appears that academic programme students place a far higher importance on academic qualifications than the other student groupings. Academic students also seem to be less realistic when it comes to their employment prospects, with a large segment indicating an expectancy of a strategic management level position in the first year after attaining their qualification, even though they do not have significant work experience.

The results furthermore provided a clear indication of the skills that are observed to be important at a number of levels, tested among employed and unemployed respondents, and across experience levels and various qualification types. The results clearly indicate that inexperienced respondents place a higher value on hard skills than on soft skills. It is only with experience that students recognise the critical nature of soft skills. This suggests that soft skills do not receive adequate attention in curriculums. The high value placed on the importance of soft skills as identified by the literature review suggests that these skills should be a key component within any curriculum design. Current curriculums focus on hard skills and do not meet the skill sets required by industry. Wong et al. (2014) and Schooley (2017) also found that soft skills were often not adequately incorporated into curriculums. According to Schulz (2008), educators have a special responsibility regarding the teaching of soft skills, because of the importance of these soft skills in the workplace. The study finds that, if South Africa is to develop competitive global supply chains, a major focus should be on the development of soft skills in tertiary curriculums. It is furthermore critical that these skills are incorporated within supply chain qualifications at the earliest opportunity.

\section{REFERENCES}

All things supply chain. 2017. 6 Supply chain skills every manager needs to know. https://www.allthings supplychain.com/6-supply-chain-skills-every-manager-needs-to-know/ (Accessed 10 August 2017).

APICS. 2014. Supply Chain Manager Competency Model. http://www.apics.org/docs/defaultsource/careers-competency-models/supply-chain-manager-competency-model.pdf (Accessed 28 
July 2017).

ATKearney. 2017. 2017 State of Logistics Report. https://www.atkearney.com/transportation/cscmp2017 (Accessed 11 August 2017).

Bak, O. and C. Jordan. 2017. Linking industry and higher education: Assessing the skills. Logistics and Transport Focus: 55-56.

Barloworld Logistics. 2016. supplychainforesight. http://www.barloworld-logistics.com/wp-content/ uploads/2016/02/supplychainforesight-2016-report.pdf (Accessed 3 January 2017).

Canadian Logistics Skills Committee. 2005. Strategic human resources study of the supply chain sector. Ontario: Canadian Logistics Skills Committee.

Clarke, A. 2016. Four reasons for the supply chain talent shortage, Part 1. http://www.sdcexec.com/ article/12154883/four-reasons-for-the-supply-chain-talent-shortage-part-1 (Accessed 28 July 2017).

De Abreu, A. and R. L. C. Alcântara. 2015. Supply chain managers: Professional profile and the role in the cross-functional integration supply chain management. Independent Journal of Management \& Production 6(1): 44-66.

DHL Supply Chain. 2017. The supply chain talent shortage: From gap to crisis. https://app.cdn. lookbookhq.com/production/clients/169/content/2017-06-07/043446/SC_Talent\%20Gap_ Research\%20Paper_EN.pdf (Accessed 29 July 2017).

Donati, M. 2015. Seven core competencies of successful supply chain leaders highlighted. https://www.cips.org/supply-management/news/2015/august/seven-core-competencies-ofsuccessful-supply-chain-leaders-highlighted/ (Accessed 19 July 2017).

Ferrari, B. 2016. What are specific skill needs and gaps in supply chain management? https:/www.theferrarigroup.com/supply-chain-matters/2016/02/26/what-are-specific-skillneeds-and-gaps-in-supply-chain-management/ (Accessed 16 August 2017).

Field, A. 2013. Discovering statistics using SPSS. $4^{\text {th }}$ Edition. London: Sage.

Gammelgaard, B. and P. D. Larson. 2001. Logistics skills and competencies for supply chain mangement. Journal of Business Logistics 22(2): 27-51.

Gunasekaran, A., N. Subramanian and S. Rahman. 2017. Improving supply chain performance through management capapbilities. Production Planning \& Control 28(6-8): 473-477.

Havenga, J. H., Z. P. Simpson, Z. P. D. King, A. de Bod and M. Braun. 2016. Logistics Barometer South Africa 2016. Stellenbosch: Stellenbosch University.

Heyns, G. and R. Luke. 2012. Skills requirements in the supply chain industry in South Africa. Journal of Transport and Supply Chain Management 6(1): 107-125.

Kisperska-Moron, D. 2010. Evolution of competencies of logistics and supply chain managers. Electronic Scientific Journal of Logistics 6(3): 21-31.

Logistics Bureau. 2016. 6 Key supply chain leaders' skills and why you need them. $\mathrm{http}: / / \mathrm{www} \cdot$ logisticsbureau.com/6-key-supply-chain-leaders-skills-and-why-you-need-them (Accessed 27 July 2017).

Logistics Bureau. 2017. Supply chain career changes - How to get in, get on, and get what you want. http://www.logisticsbureau.com/supply-chain-career-changes-how-to-get-in-get-on-and-getwhat-you-want/ (Accessed 29 July 2017).

Mangan, J. and M. Christopher. 2005. Mangement development and the supply chain manager of the future. The International Journal of Logistics Management 16(2): 178-191.

Mangan, J., O. Gregory and C. Lalwani. 2001. Education, training and the role of logistics managers in Ireland. International Journal of Logistics: Research and Applications 4(3): 313-327.

Material Handling and Logistics. n.d. What skills are supply chain managers lacking? http://www.mhlnews.com/labor-management/what-skills-are-supply-chain-managers-lacking (Accessed 12 August 2017). 
McAvoy, K. 2016. 3 Skills supply chain managers need today. https://spendmatters.com/2016/04/12/3skills-supply-chain-managers-need-today/ (Accessed 29 July 2017).

McCrea, B. 2012. Supply Chain Management Review. http://www. scmr.com/article/what_ hiring_managers_are_looking_for_today (Accessed 31 January 2017).

Mehta, A. 2015. Shortage of supply chain professionals: Some facts. https://www.linkedin.com/ pulse/shortage-supply-chain-professionals-some-facts-arvind-mehta-4 (Accessed 12 August 2017).

Noble, D. 2015. The skills shortage facing global supply chains. http://www.supplychaindigital. $\mathrm{com} / \mathrm{scm} /$ skills-shortage-facing-global-supply-chains (Accessed 29 July 2017).

Pallant, J. 2016. SPSS Survival Manual. 6th Edition. New York: McGraw-Hill Education.

Rahman, S. and L. Yang. 2009. Skills requirements for logistics managers in China: An empirical assessment. IIMB Mangement Review 21(2): 140-148.

Rahman, S. and N. Qing. 2014. Graduate students' perception of supply chain skills for supply chain managers. Benchmarking: An International Journal 21(2): 276-299.

Razzaque, M. A. and M. S. Bin Sarat. 2001. Skills requirements: perception of the senior Asian logisticians. International Journal of Physical Distribution and Logistics 31(5): 374-395.

Schooley, R. 2017. Why are soft skills missing in today's applicants. s.1.: Murray State University.

Schulz, B. 2008. The importance of soft skills: Education beyond academic knowledge. NAWA Journal of Language and Communication 2(1): 146-154.

Shou, Y. and W. Wang. 2017. Multidimensional competences of supply chain managers: An empirical study. Enterprise Information Systems 11(1): 58-74.

StatsSA. 2017. The South African economy shrinks by 0,7\%. http://www.statssa.gov.za/?p=9989 (Accessed 13 August 2017).

Thai, V. V., S. Cahoon and H. T. Tran. 2011. Skills requirements for logistics professionals: Findings and implications. Asia Pacific Journal of Marketing and Logistics 23(4): 553-574.

Wong, C. Y., D. B. Grant, B. Allan and I. Jasiuvian. 2014. Logistics and supply chain education and jobs: A study of UK markets. The International Journal of Logistics Management 25(3): 537-552.

World Bank. 2016. Logistics Performance Index 2016. https://lpi.worldbank.org/international/global (Accessed 29 July 2017).

World Economic Forum. 2015. The Global Competitiveness Report 2015-2016. http://www.weforum. org/reports/global-competitiveness-report-2015-2016 (Accessed 1 November 2015).

World Economic Forum. 2017. South Africa must resist the dangerous spiral of economic nationalism. https://www.weforum.org/agenda/2017/05/south-africa-economic-nationalism/ (Accessed 29 July 2017). 